\title{
Reading the World in the Word: The Possibilities for Literacy Instruction Framed Within Human Rights Education
}

\author{
JUDITH DUNKERLY-BEAN \\ Old Dominion University
}

\begin{abstract}
The purpose of this critical ethnography was to investigate the experiences of teachers and students when literacy instruction was framed within human rights education. Informed by cosmopolitan and critical socio-cultural theory incorporating Freirean concepts of critical literacy and praxis, this study highlights the experiences of two servant leader interns (teachers) and sixteen scholars (students) participating in human rights education sessions within the context of a Children's Defense Fund (CDF) Freedom School. Data sources included semi-structured and informal interviews, scholar and intern artifacts including multimedia projects, and recorded classroom discussions. Data were analyzed utilizing Michel Foucault's concept of "regime of truth" in order to examine how the CDF Freedom School and Human Rights Education articulated notions of freedom, knowledge, rights and power as a counter-narrative to the dominant discourse in literacy education. The findings indicate that while both discourses sought to empower students through literacy and in learning of their rights, the particular naming of literacy, identity and rights within each were constraining as well as liberating for the participating scholars. A key implication of this study is the need for a cosmopolitan critical literacy in both discourses that recognizes the need for global and local literacies, identities and rights for $21^{\text {st }}$ century adolescents.
\end{abstract}

\section{Introduction}

The hot Tennessee sun blazed down on the boy. His clothing tattered and his thin wrists encircled by rough chain links, he waited to be taken to the plantation. He had heard the stories of how slaves were treated there and he shivered despite the oppressive heat. Those around him either didn't notice, or paid no mind to his discomfort. He tried to remember his mother and aunt's words urging him to be brave; he took a deep breath as he was jostled and pushed up the steps to the wagon that would take him away. Would it have been better to accept the Confederate uniform? Would he be in this place now if he had? Garrison didn't know. One thing was certain - in making that decision he now stood alone.

Although the above passage may sound like a slave narrative from more than a century ago, in actuality it was a story told to me by my nephew Garrison this past summer. In preparation for a visit to a plantation near his school in Tennessee, the 4thgrade teachers instructed the boys in his grade to rent or create Confederate soldier uniforms, while the girls were asked to wear dresses common to the Civil War era. As a child who self-identifies as African-American, and as one of only four minority children 
in the entire grade level, Garrison, felt that it was "not OK at all" to wear a Confederate uniform, especially since his father's family descended from Southern slaves.

When he went home from school the day before the field trip, he told his mother (my sister) what was planned. Both Kelly and her visiting sister-in-law, Nakita were shocked. An African-American activist, Nakita told Garrison what would have happened to him if he had been born on a Tennessee plantation during that era. As the mixed-race baby of a white woman, he would likely have been murdered and his mother beaten or murdered herself. Now, Garrison was sure- he could not wear that uniform and act like it was "just" a costume. With Kelly and Nakita's help, he put together an outfit that would have been similar to the clothing worn by slaves, complete with a chain about his waist and wrists.

As he waited for the school bus the next morning, Kelly and Nakita urged him to be brave, but warned him that he might face ridicule from his classmates or earn the displeasure of his teacher. Garrison momentarily wavered, but then grew more resolved. He walked up the steps of the school bus with only the slightest glance back. Garrison did face ridicule from his classmates who giggled and snickered and then left him in silence for the rest of the day. When the field trip was over, the students returned to their classrooms for a follow-up project: they made Confederate flags. When Kelly called the school to question the appropriateness of the field trip requirements and follow-up activity, she was told, "This is Tennessee, we are proud of our history."

While it might be tempting to regard this story as one school's blatant insensitivity, I believe it represents an analogy to American education in which some children are marginalized by literacy practices mired in an outdated model that reinscribes and reproduces an inequitable status quo that prepares only a few for full democratic participation (Janks, 2010). Although not the only factor in the perpetuation of social inequality, the current state of literacy education highlights the need for human rights education (HRE) as a vital, yet still absent part of education in the United States today. It is in the notion of HRE informing and being informed by the lived through experience of all participants that is the greatest theoretical justification for literacy education to be situated within the context of human rights. Thus the research question that guided this study sought to answer, "What is the nature of the experience of literacy instruction for participants articulated within a human rights education (HRE) framework?" Drawing from Hicks (2002) view that "research writing is a form of social action...that seeks to confront the hegemony of educational systems" (Cherland \& Harper, 2007, p. 215) the purpose of this research is to ground literacy instruction within HRE in such a way that students learn of their human rights, but also heed the call to social action that in turn positions them as both local and global citizens with rights and responsibilities to themselves and others.

\section{Literature Review}

Literacy is a human right, a tool of personal empowerment and a means to social, cultural, and human development. Yet the nature and use of literacy, for whom, under which circumstances, and for what purposes is a contentious question that depends greatly on the social views, cultural capital, politics, and temporality of both its teachers, students, and the communities of discourse in which they participate (Foucault, 1972; Gee, 1996). The primary preoccupation of critical pedagogy then, is social injustice and 
how to transform inequitable, undemocratic, or oppressive institutions and social relations. Historically, who is considered literate and what literac(ies) are considered to be worth knowing are dependent on dominant societal constructs. Carl Kaestle (1991) points to the inherently social and political aspects of literacy in stating, "Literacy is discriminatory with regard to both access and content. Problems of discrimination are not resolved just because access is achieved; there is a cultural price tag to literacy. Thus, whether literacy is liberating or constraining depends in part whether it is used as an instrument of conformity or creativity (p. 30).

In an age of globalization, where students' identities are both global and local (Beck, 2002; see also Apple, Kenway, \& Singh, 2005), the ways in which a child's perceptions and relations are shaped have an even greater consequence in a world where both literal and figurative borders are becoming increasingly permeable.

\section{Human Rights Education}

Human rights education does not seek to create a sense of benevolent advocacy and the need for charity, nor does it attempt to present students with a value-neutral view of global issues. Rather it seeks global social justice achieved through post-national citizenship (or cosmopolitanism), solidarity, and the transformative potential of the individual through collective action brought about by a strong sense of moral purpose (Hull \& Stornaiuolo, 2010; Mundy, Manion, Masemann \&Haggerty, 2007). The overarching goals of human rights education are to teach people to respect others, engage in active citizenship, while concomitantly serving as stewards for our planet's resources in responsible and mindful ways (Anderson, 1977; Case, 1997; Hanvey, 1976; Hicks,2002: Pike \& Selby, 1988, 1999, 2000; Richardson, 1979). While the U.S. has in many cases eliminated HRE, it has been implemented in many countries to various extents and levels of success.

In a study that charted global education across Canada, Karen Mundy (2007) and her colleagues reported that the existence of a global education curriculum did not necessarily translate to a shift in practice. When global education was embraced, Mundy et al reported "fund raising for charity was mentioned as the main global education activity undertaken" (p. 99). The researchers expressed their concerns that while fundraising itself is representative of taking social action, it reinforced the "them/us" dichotomy that further marginalized minority and/or indigenous cultures.

These issues are not unique to Canada. Research from the UK indicates that teachers are didactic in their instruction and tend to be very selective in the human rights/global issues they address in their classrooms (Griffiths, 1998). Moreover, although teachers in the UK saw human rights education as being a curricular priority, they also tended to focus on themes such as cooperation and caring rather than on more controversial issues (Davies, Gregory, \& Riley 1999; Davies, 2006; Robins, Francis, \& Elliott 2003). To date, literacy education has not been studied specifically as a site for implementing HRE.

\section{Theoretical Framework}

Against an overarching framework of critical socio-cultural theory (Moje \& Lewis, 2007), I drew from Paulo Freire's concepts of praxis and the vital nature of reading both the world and the word in realizing the promise of freedom in education (Freire, 1970). Freire's view of education as the practice of freedom is essential in 
recognizing the tenets of human rights education. I also sought to disrupt the predominantly Western notion inadvertently enforced by the media, that suffering and human rights violations mostly take place in a far removed "Somewhere Else" and should be the object of pity and financial charity rather than local action. The very heart of HRE lies in the mutually informing notions of recognition of fundamental rights, liberation and transformation.

Thus, in order to both teach and honor children's rights in education, I utilized the tenets of HRE, namely:

1. Respect and realization of inherent human dignity and human rights

2. Curiosity about cultural/social issues

3. Appreciation of different cultures

4. Justice and fairness

5. Conflict resolution

6. Empathy for others

In engaging students in literacy instruction framed in HRE and social action, I drew from cosmopolitan theory. Within the context of education, the philosophy of cosmopolitanism has been used to address the effects of globalization on formal education (Hull \& Stornaiuolo 2010; Goldstein, 2007; Tierney, 2006), and speaks to a sensibility that addresses diversity intensified by globalization. It is at once a condition, a practice and a disposition (Harper \& Bean, 2009). While there are many definitions of cosmopolitanism, for the purposes of this study, I focused on the tensions and possibilities of living (and learning) in the interface of the local and the global.

\section{Context}

\section{Methodology}

Modeled after the 1964 Freedom Schools, the Children's Defense Fund (CDF) Freedom Schools draw from similar tenets of providing a quality educational experience for marginalized children, especially students of color. Established in 1995 by the Children's Defense Fund, as part of its Leave No Child Behind movement (not to be confused with President G.W. Bush's subsequent No Child Left Behind Act) the contemporary Freedom Schools originated in a division of the CDF called the Black Community Crusade for Children (Jackson, 2006).

According to the figures given in the 2010 Ella Baker Institute Training Agenda, CDF Freedom Schools served over 9,500 children in 145 sites in 84 cities and 30 states (Children's Defense Fund, 2010). Since its inception in 1995, over 80,000 children have attended CDF Freedom School nation-wide, and over 7,000 college students and 1,500 other adults have participated in this program through partnerships with local schools, universities, churches and community groups to offer the summer program. The Freedom School staff is largely comprised of "servant leader interns", 19-30 year-olds who must have at least one year of college and have plans to complete their degree. The development of the "servant-leader" is integral to the Freedom School philosophy that in order to lead, one must first serve. Similarly, the conscious choice to refer to the children and adolescents participating in Freedom Schools as "scholars" underscores the potential that each child has and is to be nurtured through the Freedom School program. 
The site for this study was a Freedom School that was held at the Umbari Charter School (pseudonym) over the course of six weeks from June 21, 2010 through July 30, 2010. Umbari is unique in the local district as a school that has African-American culture and heritage as its focus. Given that it is also situated in an economically depressed, socially marginalized, historically Black neighborhood, it offers a parallel education for young African-Americans that echoes the intent of the original Mississippi freedom schools in the summer of 1964. Within the local and regional context of this study, this particular CDF Freedom School site is the only one of its kind in this state, and one of only four on the West Coast. Although not drawing from the Universal Declaration of the Rights of the Child per se, Freedom Schools are organized around similar beliefs and engage in activism to promote children's rights.

\section{Participants}

Rather that acting as a participant/observer, I chose to engage in what Conquergood (1982) terms dialogic co-performance. As I had completed the Freedom School national training and was a fully participatory servant-leader intern at the local site, this engagement allowed for two other servant leader interns and 16 Level III scholars (students in grades 6-8) to co-create the study with me. Given Freedom School requirements, the scholars were divided randomly into two classes. One class was led by Earl (all names are self-selected pseudonyms), a 27 year-old graduate student and the other class was led by Rihanna, also a 27 year-old graduate student. Both servant leader interns were in their first year at the Freedom School. The scholars ranged in age from 11-13 and were equally represented between male and female. 13 scholars self-identified as Black or African-American, one identified as Hispanic, one as White, and one scholar self-identified as "Black-White." Most scholars resided in the neighborhood where Umbari Charter School was located and many had either attended or had a sibling currently attending the school.

\section{Human Rights Curriculum}

In keeping with Blackburn and Clark's (2007) principles for global/local research, we began with the local - the students' interests, expanding the focus to global issues related to those concerns and then returning to the local to engage in transformative social action. Curriculum sources were drawn from United Nations Children's Fund, (formerly United Nations International Children's Emergency Fund) or UNICEF, Amnesty International, and Youth for Human Rights. I also included complementary multi-literacy texts such as videos, blogs, and child/student created documentaries centered on human rights issues. As social action is also a part of the Freedom School philosophy, the culminating experience for all students was a video of their design that incorporated music, images and their own reflections on human rights as they experienced them locally, as well as in the global sphere. The video was shared at the Freedom School Finale for parents and other community stakeholders, and may also be viewed at the following site: http://www.youtube.com/watch?v=0d6xXxbiE34

\section{Freedom School Curriculum}

The Integrated Reading Curriculum (IRC) serves as the organizing component of the Freedom School program. It provides both the curriculum and the pedagogy of the 
Freedom School. Organized around the theme I Can Make a Difference, the literature selected for the IRC focuses on the weekly themes of making a difference in self, family, community, country and world with hope, education, and action. One aspect of the IRC that sets it apart from other summer literacy enrichment programs is its focus on aesthetics rather than mechanics of reading. Indeed, the training materials provided by Freedom Schools emphasizes that the IRC is designed not to teach reading, but rather to foster an enjoyment of reading. Although engagement and motivation are crucial to reading success, the lack of emphasis on mechanics meant that the servant-leader interns received no professional development on helping students who were struggling readers. The IRC's exclusion of reading strategies meant that some scholars were essentially unable to access the texts.

\section{Data Collection and Analysis}

Data collection for this study took place at the CDF Freedom School national training, the Ella Baker Child Policy Training Institute held in Knoxville, Tennessee as well as at the local site from May- July 2010. Data collected included field notes resulting from the training sessions, discussions, classroom interactions, observations, interviews with the Servant Leader Interns, and various artifacts including a music video.

Borrowing from Gore's (1993) analysis of radical pedagogical discourses through Foucault's (1980) concept of 'regime of truth', I examined how the CDF Freedom School and Human Rights Education operate as regimes of truth in framing power, rights, identity, and literacy. Analysis was on-going and recursive. I coded the data thematically to explore how literacy framed within human rights education and the CDF Freedom School articulated their regimes of truth:

1. Literacy as power (empowerment)

2. Identity

3. Rights

I utilized Michael Foucault's (1980) concept of "regime of truth" in order to make sense of the ways the CDF Freedom School and its curriculum and pedagogy acts as a counter-narrative to the dominant discourse in education, and the ways in which these notions impacted and interplayed with my implementation of literacy framed within human rights education curriculum. I present the data thematically for each discourse in keeping with the regimes of truth listed above.

\section{Findings}

In the section that follows, I explore the ways a cosmopolitan approach to critical literacy and human rights education and the CDF Freedom Schools each encompass a discourse or regime of truth that operated interdependently and influenced each other in this study. For the sake of clarity, and because it is difficult if not impossible to separate my use of critical literacy practices from my implementation of human rights education, I will examine them together as an approach, recognizing the theoretical differences.

\section{Literacy as Power in Human Rights Education}

From a Freirean perspective linking literacy and social transformation, I saw the possibilities in faming cosmopolitan critical literacy as a pedagogy of freedom well suited to reading both the "word and the world" of human rights by marginalized adolescents. 
Interns Rihanna and Earl also expressed the belief that literacy is a commodity that serves to protect human rights. Given that the Freedom School equates illiteracy with slavery it is not surprising that they linked literacy to the recognition of rights, especially for children of color. On several occasions, Rihanna told the scholars, that "the one thing separating the "haves and the have-nots" was the ability to read." On another, she lectured the scholars to take reading seriously, saying, "If you want to hide something from Black people, you put it in a book. People in power have always known this, why do you think it was illegal for slaves to read?" Earl, too, frequently admonished the scholars to remember that "if you can't read, you don't have anything...you need to take this seriously...its not a game." As both my framing of literacy as a key to unlocking human rights, and Rihanna and Earl's framing of literacy as a powerful commodity long denied in Black history, it is perhaps not surprising that we looked to the HRE curriculum as a vehicle for instruction and an empowering experience for the scholars.

As a regime of truth, literacy as power was both embraced and resisted by the scholars. At times they voiced the notion that literacy operated as a powerful commodity, and at others many actively resisted engaging in literacy related activities aimed at furthering both their literacy and their understanding of human rights. Having rejected the idea of journals and most other forms of written responses as being "too much like regular school", the scholars, interns and I turned towards drama, art, music and technology to explore human rights. Those scholars who evidenced more developed literacy skills recognized and frequently cited evidence of how literacy, personal power, and the realization of rights were intertwined somewhat more than those who struggled with reading and writing during the curricular portion of the Freedom School day. In a discussion that centered on having rights wherever you go (Article 6), Lil' Doc explained:

"No one can keep you down if you can read your rights. People who cannot read get their rights (expletive) with."

Similarly, Keisha stated, "People have to know the rules...read the rules...y'know? Then they can tell if the rules are fair... That goes worldwide... People who can't read got no power, (emphasis added) they haven't got rights."

When asked by Rihanna to clarify whether "people who can't read" shouldn't have rights, or whether they were at a disadvantage in recognizing them, Keisha, thought they did "deserve" rights but couldn't "defend themselves against people messing with their rights." Keisha voiced a belief held by many of the scholars and intimated in the HRE curriculum that being able to read was a "possession" that safeguarded human rights in lesser or greater quantity by virtue of the literacy of the individual.

\section{Literacy as Power in the CDF Freedom School}

Literacy as power is a recursive theme in the CDF Freedom School. "Illiteracy is the new slavery" serves as an unofficial mantra. One of the ways that the current Freedom School presents literacy as a powerful commodity is through the Integrated Reading Curriculum. Yet, I suggest that the selection of texts and the activities required in the IRC construct a regime of truth that privileges a particular way of knowing that emphasizes the violation of Black Civil Rights. I further suggest that the IRC as a particular "canon" of literature resulted in unintended consequences for the scholars" global perception of rights In the Introduction to the IRC, some of the features of the 
books that serve as official criteria are listed. They include books that among other requirements:

- Reflect the children's own images

- Relate authentic history, culture and heritage through the eyes of children

Within these publicly stated criteria, it is evident that the Freedom School has predetermined that since the majority of the books feature Black characters, that curriculum is designed primarily for Black children. Unlike Morrell's work (2008) that seeks to deconstruct Black images through the examination of popular culture and critical literacy, these three strata of identity: race, culture/heritage and experience as presented in the IRC as "reflecting children's images" may be problematic in their homogeneity. In viewing the curriculum as a regime of truth that promotes a particular identity and notion of freedom for Black adolescents, the IRC's engages in practices with "sufficient regularity to enable their immanent naming" (Gore, 1993, p. 56). Indeed, it names a particular identity and way of being in the world for the scholars that is more nationalistic than global in respect to their identity, their freedom and what they perceived as "rights."

\section{Texts that Reflect the Children's own Images}

In all three realistic fiction texts by noted young adult author Sharon Flake (Begging for Change and Bang!) and Shelia P. Moses (Joseph) each of the main characters struggle for safety and security in lives threatened by violence, drugs, and poverty. All are described as African-American, and all live in marginalized, lower socio-economic areas in the U.S. However, if the criteria to include literature in the IRC is that it "reflects the children's own image" and if the only realistic fiction books included in the IRC portray lives in duress, then what conclusion are the children who read these books to draw about their dreams and their futures?

Given that these are the first three novels and also represent $50 \%$ of the total books read in Level III, the scholars are inducted into the Freedom School by reading about and possibly identifying with characters that re-inscribe a marginalized identity in a divisive American society. While it is not my contention that adolescents should not read challenging or controversial texts, it is my concern that as these books are carefully chosen and as they all center on marginalized Black adolescents identified solely as African-American living in oppression, it contains a message of sufficient regularity that creates a particular construction of the power and possibilities available for those engaging with the texts.

\section{Texts that Relate Authentic History, Culture Heritage through the Eyes of Children}

After having read three novels that depict African-American adolescents living in conditions that threaten not only their rights, but their lives as well, the IRC shifts to texts exploring the history, culture and heritage of Blacks in America. In Claudette Colvin: Twice Towards Justice by Phillip Hoose, the scholars read about the Civil Rights Movement through the story of Claudette Colvin, a 15 year-old student who pre-dated Rosa Parks in refusing to give up her seat to a White woman on a segregated bus in Montgomery, Alabama. Here, much like in the realistic fiction novels, power is a possession-usually gained by "taking it back" from those who oppress - in this case, racist White society of the Civil Rights Era. 
The fifth book read by the scholars, was Sharon Draper's novel Copper Sun. Read during the themed week of "Making a Difference in my World", this novel tells the tale of Amari, a teenager who watches helplessly as her family is murdered and her village burned before she is captured and sold as a sexual slave in the Carolinas. Despite witnessing or experiencing almost every abominable act perpetrated on slaves in the South, Amari eventually escapes the plantation after the owner brutally murders his wife's lover (a slave) and their baby.

If the mission of the Children's Defense Fund including the CDF Freedom School is to "provide a strong, effective, and independent voice for all the children of America who cannot vote, lobby or speak for themselves" (Integrated Reading Curriculum, 2010, p. 246), emphasis in the original) yet, the voice heard in the curriculum is of one race and culture only, where are the children not represented in the text to find their reflection? As one of the scholar-participants, Keisha emphatically stated, "We are not all "AfricanAmerican" you know! I'm Black but I'm not from Africa, my family is from somewhere else." Her sentiment was strongly supported by nearly all of the other scholars.

Thus, in selecting books that "reflect" the children, (albeit of one race/cultural identity) there is a reification of identity in selecting books that only relate to a particular naming of culture, history and experience. Moreover, in these texts, power is portrayed as something to be wrested from the hands of a (White) oppressor, which although historically grounded becomes a meta-narrative that greatly influenced how the scholars viewed their human rights and the rights of others in the current age, not just within the bounds and boundaries of the United States, but on a global scale as well.

Viewed as a regime of truth that influence the scholars' perceptions of the world, it is of little surprise that Keisha entered class one afternoon declaring, "Black people are the only ones who have ever done any good in this world. All that Whites have done is mess it up." Although she quickly turned to me and amended her statement with "I don't mean you...you're OK", her classmates met Keisha's pronouncement with general agreement and similar statements.

I do understand that one of the stated goals of the current incarnation of the Freedom School echoes that of the 1964 Mississippi Freedom Schools: to create a sense of pride about Black history among young people. However, there is an inherent difference between the youth of 1964 and those of the present. The youth of today are living in an increasingly globalized world with borders that are literally and figuratively permeable and fluid (Beck, 2010; Hull \& Stornaiuolo, 2010). Although time constraints of a six week program mean that curriculum choices must be made that include some texts, while necessarily excluding others, in presenting only the African-American experience at the expense of other races, cultures and creeds, the CDF Freedom School, whether intentionally or not, potentially narrows the world view and perception of rights of those students it wishes to advance.

\section{Rights as a Construct in Human Rights Education}

Despite being subjected to arguably non-democratic educational settings and a reified literacy curriculum in the local district, when I asked the scholars if they have all of their rights (especially as they pertain to education), all assured me they did-“" because we live in America." Yet, as Bean and Harper (2006) remind us this sort of apple pie simplicity "cr(ies) out for more in-depth analysis" (p. 97). For when they were 
discussing the Right to Marriage or the Right to Nationality, the scholars expressed some discrimination towards those they called "illegal immigrants", the homeless, or those who identified as Lesbian, Gay, Bisexual or Transgendered LGBT. They also expressed some cynicism at how much change might be possible as a result of human rights education, as evidenced in this discussion which occurred near the end of the study:

Rihanna: So what does all of this stuff mean? What do we do with human rights, what do they mean to you?

Raspberry: They mean that there is certain stuff you can do, you can tell people about their rights...

Thunderman 24: Yeah, but what people? Who is going to tell them? I'm not going around to some homeless dude and tell him about his rights. What good would that do? Ain't going to feed him...(laughs)

Joslyn: (cutting in) Yeah, but...if you know your rights, you might feel bad if other people don't know their rights or bad things happen to them.

Breona: So if people knew about their rights, would bad things still happen, still go on around the world?

Thunderman 24: (laughing) yeah they would, just knowing don't change anything... some places are just messed up!

Angel: Yeah, but if you started with little kids it would make a difference - they would come up (grow up) with it maybe....

Miles: I think you can teach the rights to little kids, but not the ones about like, um gays getting married or like illegal Mexicans ...just like civil rights, not all the human rights...the rest are too much...

Judith: So why just civil rights, why are the rest too much?

Miles: Because the ones about the other stuff might scare little kids like the torture one, or maybe not, but like some of them aren't legal here, so you know...it doesn't fit.

In trying to draw the conversation towards how rights are influenced and constructed by social "norms" and biases, the scholars did not see that rights (as described in the United Declaration of Human Rights (UDHR) of certain groups are violated and that the violations are frequently socially tolerated. If excluded, they construct a regime of truth regarding who is empowered, who has rights, and how they can ultimately be invoked. Moreover, in employing HRE from a critical literacy approach we can also "seek answers to the questions and issues of representation and power, the positioning of the self and other and the nature and possibility of agency" (Bean \& Harper, 2006, p. 97).

\section{Rights as a Construct in the Freedom School}

Of particular concern to this study was that after engaging for the majority of the day in discussions/activities related to texts that portrayed African-Americans as marginalized and victimized by the dominant society, the scholars had difficulty in viewing rights as anything other than the fight for civil rights for African-Americans. All of the rights (including those to education) that we learned about were linked inextricably in their discussions and artifacts to rights for African-Americans. Except for two 
discussions around human trafficking and child brides as forms of modern day slavery, the scholars equated rights and power with civil rights, rather than as a global imperative.

In a questionnaire that the scholars were asked to complete both at the beginning of the study and at its conclusion, one of the questions asked, "What do human rights mean to you?" Responses from the first week of the study largely focused on rights as the absence of discrimination based on skin color and on equality. Indeed, the scholars' responses echoed Berlin's (1958) still oft-quoted lecture on negative and positive freedom, with most responses focusing on negative or external freedom. Berlin characterizes negative freedom as the absence of barriers or influences that curtail personal freedom (freedom from), whereas positive freedom deals with a broader spectrum of internal constraints including the psychological (fears, compulsions, desires) that influence what one does or does not do. Similarly, the scholars' comments illustrate a focus on the absence of barriers to individual freedoms, but to a lesser extent on a broader view that would encompass societal change. Representative comments included:

- Nobody should be discriminated against because of their skin color. Everyone should be treated equally.

- Human rights means to me that people have the right to fight for what they believe in, like civil rights

Responses from the end of the study maintained the previous focus on freedom, but also incorporated elements of power:

- It means to me that you have the power and right to do anything and nobody can push you down.

- It means that whatever color (you are) or where ever you go, you have rights.

- They mean freedom, equality and education and that's why we are here.

There is some evidence that the scholars began to grasp rights on a more global view encompassing elements of positive freedom ("You have rights wherever you go") especially as portrayed in the creation of their music video, yet it is also evident that the Civil Rights inspired curriculum of the IRC to some extent limits the views and definition of rights to those denied and fought for within the context of the United States. For adolescents living in a globalized post-Civil Rights Movement era, that definition is limiting and made it difficult for them to see rights as more encompassing than the particular experience of a particular group.

Although the regimes of truth named here for both entities could be debated, it is my belief that they describe and inform the work to be done within and across counternarratives such as the CDF Freedom School and Human Rights Education. As stated earlier, I utilized 'regimes of truth' not to disparage one approach or position one as inherently more (or less) liberating than the other. Indeed, as Foucault (1983) states, "If everything is dangerous, then we always have something to do" (p. 231). Rather, I hoped to illuminate the promise and perils of incorporating two sites and approaches doing radical work. As Harper and Bean (2006) remind us "radical literacy supports a democracy that demands plurality, along with an education that acknowledges the shifting and multiple reading and writing practices of the nation's youth (p. 153).

\section{Discussion}

In discussing the findings of this study, I utilize a cosmopolitan lens that may offer a way of re-envisioning literacy, rights and notions of freedom in an age of 
globalization; and what that might mean for adolescents as they read both the word and the world.

\section{Literacy as Power}

In both Human Rights Education and in the CDF Freedom School, literacy is frequently named as empowering and essential for the recognition of rights. Whether in viewing illiteracy as the new slavery as argued by Marian Wright Edelman and the CDF, or as implicit in the lack of global human rights (Tomasevski, 2003), the power of literacy as a liberating force in both discourses cannot be understated. Yet literacy was also frequently framed within practices that privileged those with more developed literacy skills, while further marginalizing those who did not. Thus, for literacy educators, especially those engaged in HRE, what is called for is a cosmopolitan sensibility that fully engages adolescents through a myriad of practices that extend past the known and familiar. This is not always a simple task. As Hansen (2010) acknowledges: "The willingness to learn from every encounter does not mean that such learning will be easy or always possible. Understanding self and other is seldom guaranteed and in any case, always incomplete (p.7).

In examining "what counts" as literacy through a cosmopolitan lens, it becomes apparent that neither this study nor the HRE curricula generally available fully embraced or utilized the multiple literacies available to the 21 st century adolescent. Indeed, with the variety of communication, social networks and virtual identities available to those adolescents with the appropriate technology, the spheres of the local and global are already intertwined. Yet as evidenced here, the literacies required for participation in that interface were not fully capitalized on when presenting literacy as a necessary, if insufficient, condition for participation as a global citizen.

As opposed to HRE, the CDF Freedom School does not claim the global as its focus. However, as one of the most powerful voices in advocacy for children today, the Children's Defense Fund operates within a globalized world, even though its efforts are predominantly confined to the United States. One of the ways that the Freedom School presents literacy as a precious commodity is through its Integrated Reading Curriculum (IRC). While composed of high quality literature by some of the foremost children's literature authors in the United States, its exclusivity of racial focus reifies the literacies and identities of the scholars engaging in it to one particular naming of Black experience: that of the African-American. When viewed through a cosmopolitan lens, literacy as power in the CDF Freedom School functions at the level of the nation-state, rather than in a global context. The majority of texts speak to the taking back of power from a dominant and oppressive discourse. Missing is any sense of reading against (Nodelman, 1993) the power structures evident in the text as well as their portrayals of Black identity and experience. What is needed then is not a re-working or abandonment of the texts included in the IRC, but rather how they are approached, especially in relationship to issues of power.

\section{Identities Local and Global}

Human Rights Education frequently positions everyone as a "global citizen" in such a way that the local is sometimes obscured. The CDF Freedom School, on the other hand, positions its scholars almost exclusively with a Black identity that is bound to the 
experiences of African-Americans in the United States. Yet, cosmopolitanism suggests that "it is possible to be a local resident and a transnational or global worker; a national and multinational citizen; a local consumer/producer and a global consumer/producer; a community member fluent in the local literacy practices, but also a global worker/citizen/consumer who has or needs multiliterate, multilingual, multimodal skills and abilities" (Bean, Harper, \& Dunkerly, 2011, p. 4). In both human rights education and in the Freedom School, reflecting on adolescent identity through a cosmopolitan lens asks us to reconfigure monolithic construction of adolescent identity and their place in a troubled world. As Lesko (2001) asks, "Can we connect and repoliticize youth's needs, for example, by linking issues of poverty with human rights issues (p. 198)?" That is, can we move beyond one identity for adolescents and in recognizing the multiplicity and fluid identities available also speak to needs that affect them all?

\section{Rights as a Construct in HRE and the CDF Freedom School}

The furthering of rights is the primary goal of both Human Rights Education and the CDF Freedom School. However, it is how those rights are framed, and for whom they are intended that differed between the two discourses. From a cosmopolitan perspective, this construction of rights, who holds them, when and where, might provide for a deeper understanding of the figurative borders that separate and oppress. What is called for then is a more pronounced bravery in HRE curriculum and for those who teach it to address not only blatant human rights violations, but also the social and cultural biases and prejudices that continue to insidiously infringe on human rights.

Within the CDF Freedom School, there is a distinct emphasis on rights as civil rights for African-Americans and other marginalized groups. This is not surprising given its roots in the Civil Rights Movement. While the rights of Blacks in America, are not yet fully realized, discrimination, poverty and lack of equitable education are violations of Human Rights as well as a civil issue. That movement from the realm of the nation-state in terms of civil rights to the realm of the global inherent in human rights speaks to a cosmopolitan sensibility and condition that might be more useful for students today.

\section{Implications}

Situating literacy within a framework of human rights education asks much from both teachers and their students, while also providing a direction for future research. As previously discussed, children and adolescents are living today in the interface between the local and the global and thus their identities and literacy needs have changed from those of previous generations (Gibson \& Rojas, 2009; Jimenez, Smith \& Teague, 2009; Luke \& Carrington, 2002; Luke \& Elkin, 1998). Yet, the literacy instruction they are most likely to receive does not take advantage of technological advances and digital literacies of the 21st century, but rather remains mired in its print history and a factory model of instruction (Bean \& Harper, 2006; Luke, 2004).

At the beginning of this article, I told the story of my nephew Garrison's fieldtrip to a Southern plantation as an allegory for the literacy instruction often received by marginalized children. I continue to reflect on both his experience as well as those of marginalized children who frequently receive a reified literacy education that results in the social reproduction of inequality, I advocate strongly for literacy instruction informed by critical pedagogy and framed within a structure of universal human rights. 
Moreover, I suggest that part of the implications of this research is a renewed urgency on the part of literacy teachers and researchers to answer Luke's (2004) call to "envision as part of our rethinking of democratic education a reconstruction of teachers and students as world citizens, thinkers, intellectuals and critics and within this context as national and community-based subjects" (pp. 1429-1431). In his question and in our potential reply lies the promise of a cosmopolitan approach to literacy and human rights education. Indeed, to answer that call is to move literacy into the realm of a human right rather than to limit it to a set of cognitive skills located solely within the individual. It also speaks to a collective responsibility as world citizens to secure equitable education, especially literacy education, for all.

The author would like to acknowledge her mentor, Dr. Helen J. Harper, for the knowledge, guidance and support that made this study possible. Amhran duit...

\section{References}

Anderson, L. (1977). Global education: An overview. Social Education, 41(4), 35-36.

Apple, M., Kenway, J., \& Singh, M. (2005). Globalizing Education: Policies, pedagogies, \& politics. New York, NY: Peter Lang.

Bean, T., Harper, H., \& Dunkerly, J. (2011). Cosmopolitanism, globalization and the field of adolescent literacy. Canadian and International Education 39(3), 1-13.

Bean, T. W. \& Harper, H. J (2006). Exploring notions of freedom in and through young adult literature. Journal of Adolescent and Adult Literacy 50(2), 96-104.

Beck, U. (2002). The cosmopolitan society and its enemies. Theory, Culture, and Society, 19(1-2), 17-44.

Blackburn, M. V. \& Clark, C. T. (Eds.) (2007). Literacy research for political action and social change. New York: Peter Lang.

Case, R. (1997). Global education: It's largely a matter of perspective. In R. Case \& P. Clark (Eds.), The Canadian anthology of social studies: Issues and strategies for teachers (pp. 75-82). Burnaby, B.C.: Simon Fraser University.

Cherland M. R. \& Harper, H. J. (2007). Advocacy research in literacy education: Seeking higher ground. Mahwah, NJ: Lawrence Erlbaum Associates.

Children's Defense Fund (2010). Summer integrated reading curriculum (Vol. 12). Washington, DC: Children's Defense Fund.

Conquergood, D. (1982). Performing as a moral act: Ethical dimensions of ethnography of performance. Literature in performance, 5(2), 1-13

Davies, I., Gregory, I., \& Riley, S. (1999). Good citizenship and educational provision. London: Farmer.

Foucault, M. (1972). The archaeology of knowledge and the discourse on language ( A. M. Sheridan Smith, Trans.). New York, NY: Pantheon Books.

Freire, P. (1970). Pedagogy of the oppressed (M. B. Ramos, Trans.). New York, NY: Herder and Herder.

Gee, J. P. (1996). Social linguistics and literacies: Ideology in discourse. London, UK: Falmer Press. 
Gibson, M. A. \& Rojas, A. R. (2006). Globalization, immigration and the education of "new" immigrants in the 21 st century. Current Issues in Comparative Education, 9(1), 69-76.

Goldstein, T. (2007). Educating world teachers for cosmopolitan classrooms and schools. Asia Pacific Journal of Education, 27(2), 131-155.

Gore, J. M. (1993). The struggle for pedagogies: Critical and feminist discourses as regimes of truth. New York, NY: Routledge.

Griffiths, R. (1998). Educational citizenship and independent learning. London, UK: Jessica Kingsley.

Hansen, D. T. (2008). Curriculum and the idea of a cosmopolitan inheritance. Journal of Curriculum Studies, 40(3), 289-312.

Hansen, D. T. (2010). Cosmopolitanism and education: A view from the ground. Teachers College Record, 112(2), 1-30.

Hanvey, R. (1976). An attainable global perspective. New York, NY: Global Perspectives in Education.

Harper, H. J \& Bean, T. W.( 2009). Adolescent literacy in a cosmopolitan age. Paper presented at the meeting of Canadian Society for Studies in Education. Ottawa, $\mathrm{ON}$.

Hicks, D. (2002). Reading lives: Working class children and literacy learning. New York, NY: Teachers College Press.

Hull, G. A. \& Stornaiuolo, A. (2010). Literate arts in a global world. Journal of Adolescent and Adult Literacy, 54(2), 85-97.

Jackson, T. O. (2006). Learning to teach in Freedom Schools: Developing practices and identities as educators and activists (Unpublished doctoral dissertation). Michigan State University, East Lansing, MI.

Janks, H. (2010). Literacy and power. New York, NY: Routledge.

Jimenez, R, Smith, P. \& Teague, B. (2009). Transnational and community literacies for teachers. Journal of Adolescent and Adult Literacy 53(1), 16-28

Kaestle, C. (1991). Literacy in the United States: Readers and reading since 1880.

New Haven: Yale University Press.

Lesko, N. (2001). Act your age! A cultural construction of adolescence. New York, NY: Routledge Falmer.

Lewis, C. \& Moje, E. (2003). Reframing sociocultural research on literacy: Identity, agency and power. Mahwah, NJ: Lawrence Erlbaum Associates

Luke, A. (2004). Teaching after the market: From commodity to cosmopolitanism. Teachers College Record, 106(7), 1422-1443.

Luke, A. \& Carrington, V. (2002). Curriculum, ethics, metanarrative: Teaching and learning beyond the nation. Curriculum Perspectives. 22(1), 49-54.

Luke, A. \& Elkins, J. (1998). Reinventing literacy in "New Times." Journal of Adolescent \& Adult Literacy, 42(1), 4-7.

for the 21st century. (pp. 64-79). Philadelphia, PA: University of Pennslyvania Press.

Moje, E. B. \&Lewis, C. (2007) Examining Opportunities to Learn Literacy: The Role of Critical Sociocultural Literacy Research. In Lewis, C. J., Enciso, P., \& Moje, E. B. 
(Eds.), Reframing sociocultural research on literacy: Identity, agency, and power. Mahwah, NJ: Lawrence Erlbaum Associates.

Morrell, E. (2008). Critical literacy and urban youth: Pedagogies of access, dissent and liberation. New York, NY: Routledge.

Mundy, K., Manion, C., Masemann, V., and M. Haggerty (2007). Charting global education in Canada's elementary schools: Provincial, district and school-level perspectives. Toronto. UNICEF-Canada/OISE/UT, 141pp.

Pike, G., \& Selby, D. (1988). Global teacher, global learner. London, UK: Hodden and Stoughton.

Pike, G., \& Selby, D. (1999). In the global classroom 1. Toronto, ON: Pippin Publishing. Pike, G., \& Selby, D. (2000). In the global classroom 2. Toronto, ON: Pippin Publishing.

Powell, R. (1999). Literacy as a moral imperative: Facing the challenges of a pluralistic society .Lanham, MD: Rowman \& Littlefield.

Richardson, R. (1979). Learning for change in world society. London: World Studies

Robins, M., Francis, L., \& Elliott, E. (2003). Attitudes toward education for global citizenship among trainee teachers. Research in Education, 69, 93-98

Tierney, R. (2006). Global/Cultural teachers creating possibilities: Reading worlds, reading selves, and learning to teach. Pedagogies: An International Journal, 1(1), 77-87.

Tomasevski, K. (2003). Education denied. London, UK: Zed Books.

Author Biography

Judith Dunkerly-Bean is an Assistant Professor of Literacy Education at Old Dominion University's Darden College of Education. Her research centers on the activism and affordances of adolescents' multimodal responses to issues of social justice and human rights. 